\title{
Successful vaccines for naturally occurring protozoal diseases of animals should guide human vaccine research. A review of protozoal vaccines and their designs
}

\author{
MILTON M. MCALLISTER* \\ University of Adelaide, School of Animal \& Veterinary Sciences, Roseworthy, SA 5371, Australia
}

(Received 9 September 2013; revised 1 November and 12 November 2013; accepted 12 November 2013; first published online 28 fanuary 2014)

SUMMAR Y

\begin{abstract}
Effective vaccines are available for many protozoal diseases of animals, including vaccines for zoonotic pathogens and for several species of vector-transmitted apicomplexan haemoparasites. In comparison with human diseases, vaccine development for animals has practical advantages such as the ability to perform experiments in the natural host, the option to manufacture some vaccines in vivo, and lower safety requirements. Although it is proper for human vaccines to be held to higher standards, the enduring lack of vaccines for human protozoal diseases is difficult to reconcile with the comparatively immense amount of research funding. Common tactical problems of human protozoal vaccine research include reliance upon adapted rather than natural animal disease models, and an overwhelming emphasis on novel approaches that are usually attempted in replacement of rather than for improvement upon the types of designs used in effective veterinary vaccines. Currently, all effective protozoal vaccines for animals are predicated upon the ability to grow protozoal organisms. Because human protozoal vaccines need to be as effective as animal vaccines, researchers should benefit from a comparison of existing veterinary products and leading experimental vaccine designs. With this in mind, protozoal vaccines are here reviewed.
\end{abstract}

Key words: Protozoal diseases, attenuation, vaccination, efficacy, review, animal models of human disease, malaria, one medicine, apicomplexa.

\section{INTRODUCTION}

Effective vaccines are available for many protozoal diseases of animals (see Tables 1-4). In contrast, no vaccine is widely available for any protozoal disease of humans, despite great need and considerable effort. Some of the more important protozoal diseases of humans for which vaccines could be invaluable include falciparum malaria, vivax malaria, Chagas' disease, African trypanosomiasis, visceral leishmaniasis, cutaneous leishmaniasis, cryptosporidiosis, and giardiasis.

In comparison to animal vaccine research, human vaccine research has an extra high hurdle in needing to test vaccine efficacy within humans themselves. Nevertheless, this problem is not insurmountable, and numerous highly credible experiments and field trials have been performed on humans (Armijos et al. 2003; Roestenberg et al. 2009; Olotu et al. 2013; Seder et al. 2013). So why is it that protozoal vaccines are only available for animals? A number of factors are suggested later in this review.

Indeed, several effective veterinary vaccines do have designs that should be suitable for human vaccines. Vaccine designs that have had repetitive

* Corresponding author: University of Adelaide, School of Animal \& Veterinary Sciences, Roseworthy, SA 5371, Australia. E-mail: milton.mcallister@adelaide.edu.au veterinary successes should be considered for adaptation for human vaccines. Protozoal vaccine scientists should familiarize themselves with the comparative performance records of the various design categories of experimental and commercial vaccines, and in particular they should analyse the properties and production methods of the best vaccines that have been used to combat animal diseases.

The following sections of this analytical review article describe the main classes of veterinary protozoal vaccine designs. Illustrative details are provided of the composition and performance of several vaccines, most of which are in current use; readers who prefer less detail may skip to the short descriptions listed in Tables 1-4. Experimental protozoal vaccines are then presented in two sections, the first describing experimental vaccines with good evidence of efficacy, and the second analysing several prominent types of experimental malaria vaccines; these are summarized in Tables 5 and 6 . Factors are then suggested to account for the general differences in performance of each of these vaccine classes, and suggestions are offered to assist in the development of effective protozoal vaccines for both animals and humans.

Throughout this manuscript, a vaccine is considered to have effective immunity or to demonstrate efficacy if it prevents infection or reduces disease 


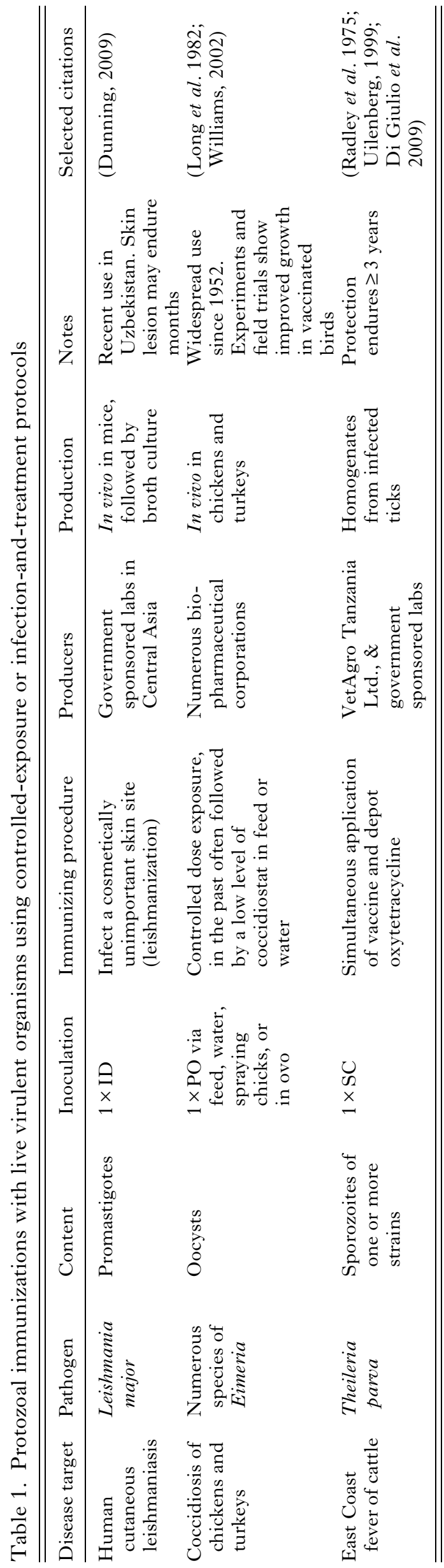

incidence or severity, provided that such benefits extend for a useful period of time under field conditions. No assumptions are made about vaccine efficacy based on humoral, cellular, or innate immune response data, or experiments in vitro or within nontarget animal models.

\section{PROS AND CONS OF VETERINARY VERSUS}

HUMAN VACCINERESEARCH

\section{Comparative advantages for veterinary vaccine development}

Vaccine development for animal diseases has the following advantages over vaccine development for human diseases.

Infectious challenge experiments. Development of vaccines for animals usually includes infectious challenge experiments using the natural animal host (Cornelissen and Schetters, 1996; Shkap and Pipano, 2000), enabling experiments with high predictive value to advance rapidly. Performing similar trials in humans has greater ethical and regulatory burdens and can be impossible or require compromise of experimental design. Therefore, initial efficacy data for humans may have to be acquired in the field under circumstances which can be difficult to control.

In vivo production of organisms. A second advantage in the development of animal protozoal vaccines is the option to manufacture vaccine organisms in vivo. Poultry coccidiosis vaccines are produced by infection of birds and collection and purification of organisms from their feces or intestines (Williams, 2002; Sharman et al. 2010). Many babesiosis vaccines are produced by infection of splenectomized animals and harvesting the infected erythrocytes (Callow et al. 1997). Although this is a clear manufacturing advantage, any vaccine that contains animal products is subject to marketing and regulatory disadvantages regarding international registration and importation.

Less rigorous regulation. Licensing requirements for human vaccines are stringent in modern industrial nations, including a requirement to demonstrate efficacy (see Gruber, 2011 for a review of US regulations). In comparison, animal vaccines have often appeared to have lower regulatory hurdles, as evidenced by commercial sales of various products prior to clear demonstration of efficacy (Choromanski and Block, 2000; Witonsky et al. 2004). Regulation of veterinary products in the European Union and the USA is becoming more rigorous (as reviewed by Schetters and Gravendyck, 2006). 
Table 2. Protozoal vaccines that contain live attenuated organisms

\begin{tabular}{|c|c|c|c|c|c|c|c|c|}
\hline Disease target & Pathogen & Content & Inoculation & Producers & Production & Availability & Notes & Selected citations \\
\hline $\begin{array}{l}\text { Toxoplasmosis } \\
\text { abortion in } \\
\text { sheep }\end{array}$ & $\begin{array}{l}\text { Toxoplasma } \\
\text { gondii }\end{array}$ & $\begin{array}{l}\text { Tachyzoites of } \\
\text { the S48 strain }\end{array}$ & $\begin{array}{l}1 \times \mathrm{SC} \text { in } \\
\text { pre-breeding } \\
\text { ewe lambs }\end{array}$ & $\begin{array}{l}\text { MSD Animal } \\
\text { Health, Toxovax }\end{array}$ & $\begin{array}{l}\text { In vitro culture in } \\
\text { mammalian cells }\end{array}$ & $\begin{array}{l}\text { New Zealand } \\
\text { and parts of } \\
\text { Europe }\end{array}$ & $\begin{array}{l}\text { Enduring protection. } \\
\text { Initial attenuation by } \\
\text { rapid passage in mice. } \\
\text { Can't encyst. In use since } \\
1988\end{array}$ & $\begin{array}{l}\text { (Wilkins et al. 1988; } \\
\text { Buxton et al. 1993) }\end{array}$ \\
\hline $\begin{array}{l}\text { Bovine tropical } \\
\text { theileriosis }\end{array}$ & $\begin{array}{l}\text { Theileria } \\
\text { annulata }\end{array}$ & $\begin{array}{l}\text { Macro- } \\
\text { schizonts }\end{array}$ & $1 \times \mathrm{SC}$ & $\begin{array}{l}\text { Primarily } \\
\text { government } \\
\text { sponsored labs }\end{array}$ & $\begin{array}{l}\text { In vitro culture in } \\
\text { lymphoid or } \\
\text { monocytic cells }\end{array}$ & $\begin{array}{l}\text { e.g. Turkey, } \\
\text { China, India, } \\
\text { Iran, Israel, } \\
\text { Spain }\end{array}$ & $\begin{array}{l}\text { Enduring protection } \\
\text { under field conditions. } \\
\text { Attenuation achieved } \\
\text { several times by adapting } \\
\text { to cell culture. Vaccine } \\
\text { organisms cannot be } \\
\text { transmitted to ticks }\end{array}$ & $\begin{array}{l}\text { (Hashemi-Fesharki, } \\
\text { 1988; Pipano, 1997; } \\
\text { Hall et al. 1999; } \\
\text { Yin et al. 2008) }\end{array}$ \\
\hline $\begin{array}{l}\text { Bovine } \\
\text { babesiosis }\end{array}$ & $\begin{array}{c}\text { Babesia bovis, } \\
\text { B. bigemina }\end{array}$ & Merozoites & $\begin{array}{c}1 \times \mathrm{SC} \text { or IM in } \\
\text { juvenile calves }\end{array}$ & $\begin{array}{l}\text { Primarily } \\
\text { government } \\
\text { sponsored labs }\end{array}$ & $\begin{array}{l}\text { In vivo in } \\
\text { splenectomized } \\
\text { calves or in vitro in } \\
\text { bovine } \\
\text { erythrocytes }\end{array}$ & $\begin{array}{l}\text { e.g. Australia, } \\
\text { Argentina, } \\
\text { Columbia, } \\
\text { Cuba, Israel }\end{array}$ & $\begin{array}{l}\text { An epidemiologic success, } \\
\text { but several vaccines can } \\
\text { induce disease ( } 2 \% \\
\text { vaccine reactions in } \\
\text { Cuba) and are } \\
\text { contraindicated in } \\
\text { adults. An in vitro } \\
\text { produced vaccine used in } \\
\text { Argentina appears to be } \\
\text { well attenuated }\end{array}$ & $\begin{array}{l}\text { (Callow et al. 1997; } \\
\text { Bock and de Vos, } \\
\text { 2001; Gerdts and } \\
\text { Ortíz, 2004; } \\
\text { Echaide, 2008) }\end{array}$ \\
\hline $\begin{array}{l}\text { Poultry } \\
\text { coccidiosis }\end{array}$ & $\begin{array}{l}\text { Numerous } \\
\text { species of } \\
\text { Eimeria }\end{array}$ & Oocysts & $\begin{array}{l}1 \times \text { PO via feed, } \\
\text { water, } \\
\text { spraying } \\
\text { chicks }\end{array}$ & $\begin{array}{l}\text { Numerous bio- } \\
\text { pharmaceutical } \\
\text { corporations }\end{array}$ & $\begin{array}{l}\text { In vivo in chickens } \\
\text { and turkeys }\end{array}$ & $\begin{array}{l}\text { Used } \\
\text { worldwide }\end{array}$ & $\begin{array}{l}\text { 'Precocious' strains select } \\
\text { short prepatency, } \\
\text { produce fewer oocysts } \\
\text { with reduced virulence } \\
\text { but greater production } \\
\text { cost }\end{array}$ & $\begin{array}{l}\text { (Jeffers, 1975; } \\
\text { McDonald and } \\
\text { Shirley, 2009) }\end{array}$ \\
\hline
\end{tabular}


Comparative advantages for human vaccine development

Research funding. Naturally, public demand is much greater for treatments and vaccines to combat human diseases than for animal diseases. As a result, vastly more funding is available for human disease research of all types in comparison with animal disease research. For example, the 2012 budget for the US National Institutes of Health (NIH, 2012), which exists to perform and support human medical research, was $\$ 25.38$ billion. In comparison, the US Department of Agriculture funds intramural animal health research via the Agricultural Research Service (ARS), and extramural animal health research via the National Institute for Food and Agriculture (NIFA). The ARS budget in 2012 that was allocated for 'animal protection', denoting animal disease research, was $\$ 0.08$ billion (USDA, 2012). The last thorough analysis of NIFA's extramural research support was for a period ending in 2007 (NIFA, 2009 ), a year when approximately $\$ 0 \cdot 05$ billion was awarded for animal disease research. Although it isn't possible to compare with precision, NIH (human) and USDA (animal) health and disease research budgets clearly differ by orders of magnitude, and similar funding trends are apparent in the size and number of private charities and commercial industries that are devoted to human or animal health. This general funding environment affects all types of disease research, including efforts to develop protozoal vaccines.

Product pricing. Manufacturers of human vaccines benefit from significantly higher prices and increased demand for their products as a result of human priorities, medical insurance, government and school policies, and international humanitarian efforts. Pricing of livestock vaccines can be meagre in comparison; poultry coccidiosis vaccines are examples of products from which manufacturers need high volumes to compensate for exceptionally low prices (Williams, 2002).

\section{TYPES OF PROTOZOAL VACCINES IN USE}

Most existing protozoal vaccines are for pathogens in the phylum Apicomplexa. Members of this phylum are obligate intracellular parasites that actively invade host cells and have both asexual and sexual reproductive cycles.

A small number of vaccines have been produced for non-Apicomplexan protozoa. These organisms only have asexual reproduction. Amastigotes of Leishmania spp. multiply within phagocytes of the vertebrate host although they do not invade non-phagocytic cells, and the promastigote stages replicate extracellularly within arthropod vectors. 
Table 4. Protozoal vaccines that contain defined antigens or antigen extracts

\begin{tabular}{|c|c|c|c|c|c|c|c|}
\hline Disease target & Pathogen & Content & Inoculation & Manufacturer & Production & Notes & Selected citations \\
\hline $\begin{array}{l}\text { Canine visceral } \\
\text { leishmaniasis } \\
\text { (in Brazil) }\end{array}$ & $\begin{array}{l}\text { Leishmania } \\
\text { infantum } \\
\text { (L. chagasi) }\end{array}$ & $\begin{array}{l}\text { Fucose mannose } \\
\text { ligand } \\
\text { glycoprotein } \\
\text { complex, with } \\
\text { saponin adjuvant }\end{array}$ & $\begin{array}{l}3 \times \mathrm{SC} \text {, then } \\
\text { annually }\end{array}$ & $\begin{array}{l}\text { Zoetis, } \\
\text { Leishmune }\end{array}$ & $\begin{array}{l}\text { Ag extracted from } \\
\text { in vitro axenic culture } \\
\text { of } L . \text { donovani } \\
\text { (not } L . \text { infantum) }\end{array}$ & $\begin{array}{l}\text { Field trials support efficacy in } \\
\text { reducing prevalence of infection } \\
\text { and disease in dogs. Injection } \\
\text { reactions common but not } \\
\text { serious. Epidemiological } \\
\text { evidence of associated reduction } \\
\text { of vector-borne zoonotic } \\
\text { transmission in Brazil }\end{array}$ & $\begin{array}{l}\text { (Borja-Cabrera et al. } \\
\text { 2002; Nogueira et al. } \\
\text { 2005; Palatnik-de- } \\
\text { Sousa et al. 2009) }\end{array}$ \\
\hline $\begin{array}{l}\text { Canine visceral } \\
\text { leishmaniasis } \\
\text { (in Europe) }\end{array}$ & $\begin{array}{l}\text { Leishmania } \\
\text { infantum }\end{array}$ & $\begin{array}{l}\text { Excreted secreted } \\
\text { proteins with } \\
\text { saponin adjuvant }\end{array}$ & $\begin{array}{l}3 \times \mathrm{SC} \text {, then } \\
\text { annually }\end{array}$ & $\begin{array}{l}\text { Virbac, } \\
\text { CaniLeish }\end{array}$ & $\begin{array}{l}\text { Ag extracted from } \\
\text { in vitro axenic culture } \\
\text { of L.infantum }\end{array}$ & $\begin{array}{l}\text { Pre-licensed formulations (with } \\
\text { muramyl dipeptide adjuvant) } \\
\text { protected dogs from infectious } \\
\text { challenge } 8 \mathrm{~m} \text { after vaccination, } \\
\text { and in a field trial showed } 92 \% \\
\text { efficacy over } 2 \text { years }\end{array}$ & $\begin{array}{l}\text { (Lemesre } \text { et al. 2005; } \\
\text { Lemesre } \text { et al. 2007) }\end{array}$ \\
\hline $\begin{array}{l}\text { Canine visceral } \\
\text { leishmaniasis } \\
\text { (in Brazil) }\end{array}$ & $\begin{array}{l}\text { Leishmania } \\
\text { infantum } \\
\text { (L. chagasi) }\end{array}$ & $\begin{array}{l}\text { A2 amastigote ag } \\
\text { linked to a } \\
\text { histidine tag, with } \\
\text { saponin adjuvant }\end{array}$ & $\begin{array}{l}3 \times \mathrm{SC} \text {, then } \\
\text { annually }\end{array}$ & $\begin{array}{l}\text { Hertape Calier, } \\
\text { Leish-Tec }\end{array}$ & $\begin{array}{l}\text { Recombinant ag } \\
\text { produced by } \\
\text { transfected E. coli. }\end{array}$ & $\begin{array}{l}\text { Licensed in Brazil since } 2007 . \\
\text { Partial protection in } 7 \text { dogs } \\
\text { demonstrated in severe IV } \\
\text { challenge administered } 4 \text { weeks } \\
\text { after vaccination. No further } \\
\text { information regarding lab or } \\
\text { field studies }\end{array}$ & (Fernandes et al. 2008) \\
\hline $\begin{array}{l}\text { Coccidiosis } \\
\text { of chickens }\end{array}$ & Eimeria spp. & $\begin{array}{l}\text { E. maxima gam56 } \\
\text { and gam } 82 \text { ag } \\
\text { with oil-in-water } \\
\text { adjuvant }\end{array}$ & $\begin{array}{l}2 \times \mathrm{IM} \text { in } \\
\text { breeding } \\
\text { hens before } \\
\text { laying }\end{array}$ & $\begin{array}{l}\text { Philbro Animal } \\
\text { Health Corp., } \\
\text { Coxabic }\end{array}$ & $\begin{array}{l}\text { In vivo growth of } \\
\text { E. maxima in chickens. } \\
\text { Gametocyte ag affinity } \\
\text { purified from infected } \\
\text { gut }\end{array}$ & $\begin{array}{l}\text { Gametocyte ag induces } \\
\text { interspecific protection. } \\
\text { Maternal immunity is boosted } \\
\text { by natural exposure of hatchlings } \\
\text { to coccidia. Each vaccine dose } \\
\text { is relatively costly, but passive } \\
\text { immunity extends to many } \\
\text { eggs/chicks. Efficacy supported } \\
\text { by challenge experiments and } \\
\text { production data }\end{array}$ & (Sharman et al. 2010) \\
\hline $\begin{array}{l}\text { Canine } \\
\text { babesiosis }\end{array}$ & $\begin{array}{l}\text { Babesia canis, } \\
\text { B. rossi }\end{array}$ & $\begin{array}{l}\text { Soluble parasite } \\
\text { ag in saponin } \\
\text { adjuvant }\end{array}$ & $\begin{array}{l}2 \times \mathrm{SC} \text {, then } \\
\text { twice } \\
\text { annually }\end{array}$ & $\begin{array}{l}\text { Out of } \\
\text { production }\end{array}$ & $\begin{array}{l}\text { In vitro in canine RBCs. } \\
\text { Ag extracted from } \\
\text { culture supernatant }\end{array}$ & $\begin{array}{l}\text { Mild-moderate reduction of } \\
\text { disease severity in vigorous IV } \\
\text { heterologous challenge. } \\
\text { Injection site reactions reported. } \\
\text { No published epidemiological } \\
\text { investigations }\end{array}$ & $\begin{array}{l}\text { (Schetters } \text { et al. } 2001 \text {; } \\
\text { Schetters et al. } 2006 \text {; } \\
\text { Freyburger } \text { et al. } \\
\text { 2011) }\end{array}$ \\
\hline
\end{tabular}


Table 5. Experimental animal and human immunizations using whole protozoal organisms ${ }^{\mathrm{a}}$

\begin{tabular}{|c|c|c|c|c|c|c|c|}
\hline Target & Animal & Pathogen & Immunization procedure & Adverse events & Challenge protocol & Results & Selected citations \\
\hline Avian malaria & Canary & Plasmodium relictum & $\begin{array}{l}\text { Sporozoites dissected from } \\
\text { mosquitoes, held in physiological } \\
\text { solution } 12-48 \mathrm{~h} \text {, and inoculated } \\
1 \times \mathrm{SC}\end{array}$ & $\begin{array}{l}\text { In } 24 \text { birds, } 1 \text { had severe } \\
\text { and } 2 \text { had weak } \\
\text { parasitaemias when } \\
\text { sporozoites held }<24 \mathrm{~h} \text {; } \\
21 \text { had no parasitaemia } \\
\text { when held between } \\
12-48 \mathrm{~h}\end{array}$ & $\begin{array}{l}\text { Birds exposed to infected } \\
\text { mosquitoes at least } \\
2 \text { weeks after } \\
\text { immunization }\end{array}$ & $\begin{array}{l}\text { All } 44 \text { control birds developed } \\
\text { malaria. Of } 24 \text { immunized } \\
\text { birds: } 1 \text { had severe, } 7 \text { had mild } \\
\text { and } 16 \text { had no parasitaemia }\end{array}$ & $\begin{array}{l}\text { (Sergent and } \\
\text { Sergent, 1910) }\end{array}$ \\
\hline Falciparum malaria & Human & $\begin{array}{l}\text { Plasmodium } \\
\text { falciparum }\end{array}$ & $\begin{array}{l}\text { Volunteers were bitten by } 12-15 \\
\text { infected mosquitoes, } 3 \times \text {, while } \\
\text { on chloroquine }\end{array}$ & $\begin{array}{l}\text { Malaria did not occur } \\
\text { during this period }\end{array}$ & $\begin{array}{l}\text { Bite of } 5 \text { mosquitoes, } 2 \mathrm{~m} \\
\text { after } 3 \text { rd exposure and } \\
1 \mathrm{~m} \text { after chloroquine }\end{array}$ & $\begin{array}{l}\text { Malaria occurred in } 5 \text { of } 5 \\
\text { control subjects but in } 0 \text { of } 10 \\
\text { immunized subjects }\end{array}$ & $\begin{array}{l}\text { (Roestenberg et al. } \\
\text { 2009) }\end{array}$ \\
\hline Avian malaria & Chicken & $\begin{array}{l}\text { Plasmodium } \\
\text { gallinaceum }\end{array}$ & $\begin{array}{l}\text { Sporozoites dissected from } \\
\text { mosquitoes and formalinized } \\
\text { (a best protocol). } 5 \times 10^{4} \mathrm{IV}, 3 \times\end{array}$ & No illness reported. & $\begin{array}{l}\text { Severe challenge with } 500 \\
\text { sporozoites IV, } 2 \text { weeks } \\
\text { after } 3 \text { rd vaccination. } \\
\text { Death as endpoint }\end{array}$ & $\begin{array}{l}\text { All } 20 \text { control birds died but all } \\
20 \text { immunized birds survived } \\
\text { with mild to minimal } \\
\text { parasitaemia }\end{array}$ & (Richards, 1966) \\
\hline Falciparum malaria & Human & $\begin{array}{r}\text { Plasmodium } \\
\text { falciparum }\end{array}$ & $\begin{array}{l}\text { Sporozoites purified from } \\
\text { mosquitoes, irradiated and } \\
\text { cryopreserved. } 1.35 \times 10^{5} \mathrm{IV}, 5 \times \\
\text { (the best protocol). }\end{array}$ & $\begin{array}{l}\text { Injection site tenderness } \\
\text { or bruising }\end{array}$ & $\begin{array}{l}\text { Bite of } 3 \text { mosquitoes, } \\
\sim 3 \text { weeks after } 5 \text { th } \\
\text { vaccination }\end{array}$ & $\begin{array}{l}\text { Malaria occurred in } 5 \text { of } 6 \\
\text { control subjects but in } 0 \text { of } 6 \\
\text { vaccinates }\end{array}$ & (Seder et al. 2013) \\
\hline $\begin{array}{l}\text { Toxoplasma gondii } \\
\text { shedding by cats }\end{array}$ & Cat & $\begin{array}{l}\text { Toxoplasma gondii } \\
\text { strain T-263 }\end{array}$ & $\begin{array}{l}\text { Bradyzoites PO, } 2 \times \text {, using sexually } \\
\text { incompetent strain }\end{array}$ & $\begin{array}{l}\text { No adverse event } \\
\text { reported. No cat shed } \\
\text { oocysts in feces } \\
\text { following ingestion } \\
\text { of } T-263\end{array}$ & $\begin{array}{l}\text { Ingestion of heterologous } \\
\text { bradyzoites in } 200 \text { cysts, } \\
47 \text { days after } 2 \text { nd } \\
\text { vaccination }\end{array}$ & $\begin{array}{l}\text { All } 6 \text { unvaccinated control cats } \\
\text { shed oocysts, but } 0 \text { of } 24 \\
\text { vaccinated cats shed oocysts }\end{array}$ & $\begin{array}{l}\text { (Freyre et al. } \\
\text { 1993) }\end{array}$ \\
\hline $\begin{array}{l}\text { Toxoplasmosis } \\
\text { transmission on } \\
\text { farms }\end{array}$ & Cat & $\begin{array}{l}\text { Toxoplasma gondii } \\
\text { strain T-263 }\end{array}$ & $\begin{array}{l}\text { Cat trapping attempted during } \\
7 \text { visits to } 8 \text { farms over } 3 \text { years. } \\
\text { Trapped cats administered live } \\
\text { cryopreserved bradyzoites PO up } \\
\text { to } 2 \times\end{array}$ & Not monitored. & n.a. & $\begin{array}{l}\text { Significantly more cats were } \\
\text { found shedding } T \text {. gondii } \\
\text { oocysts prior to vaccinations. } \\
\text { Progressive, statistically } \\
\text { significant reductions of } \\
\text { infection prevalence in pigs and } \\
\text { in trapped mice on farms }\end{array}$ & $\begin{array}{l}\text { (Mateus-Pinilla } \\
\text { et al. 1999) }\end{array}$ \\
\hline $\begin{array}{l}\text { Cutaneous } \\
\text { leishmaniasis }\end{array}$ & Human & $\begin{array}{l}\text { Three Leishmania } \\
\text { spp. isolates from } \\
\text { Ecuador }\end{array}$ & $\begin{array}{l}\text { ID, } 2 \times \text {, killed promastigotes, mix } \\
\text { of } 3 \text { isolates produced in vitro. } \\
\text { BCG adjuvant }\end{array}$ & $\begin{array}{l}\text { Minor local effects of } \\
\text { inoculation and mild } \\
\text { fever following } 2 \text { nd } \\
\text { vaccination were } \\
\text { reported }\end{array}$ & n.a. & $\begin{array}{l}\text { Within } 1 \text { year of vaccination, } 2 \% \\
\text { of vaccinates vs } 8 \% \text { of controls } \\
\text { had an episode of cutaneous } \\
\text { leishmaniasis. Protective } \\
\text { efficacy }=73 \%\end{array}$ & $\begin{array}{l}\text { (Armijos et al. } \\
\text { 1998) }\end{array}$ \\
\hline $\begin{array}{l}\text { Cryptosporidiosis } \\
\text { diarrhoea }\end{array}$ & Cattle & $\begin{array}{l}\text { Cryptosporidium } \\
\text { parvum }\end{array}$ & $\begin{array}{l}1 \times, \mathrm{PO} \text { oocysts, killed by } \\
\text { lyophilization, at } 0-1 \text { day age }\end{array}$ & None reported & $\begin{array}{l}10^{5} \text { live oocysts } \mathrm{PO} \\
\text { at } 7 \text { days age }\end{array}$ & $\begin{array}{l}\text { In } 10 \text { controls and } 9 \text { vaccinates, } \\
\text { mean duration of diarrhoea was } \\
4 \text { vs } 1 \cdot 7 \text { days, and mean } \\
\text { duration of oocyst shedding } 5 \cdot 3 \\
\text { and } 2 \text { days, respectively }\end{array}$ & $\begin{array}{l}\text { (Harp and Goff, } \\
1995 \text { ) }\end{array}$ \\
\hline Histomoniasis & Turkey & $\begin{array}{l}\text { Histomonas } \\
\text { meleagridis }\end{array}$ & $\begin{array}{l}1 \times, \text { PO, live, in vitro high-passage } \\
\text { attenuated trophozoites into the } \\
\text { crop of } 1 \text { day old poults }\end{array}$ & $\begin{array}{l}\text { No clinical signs nor } \\
\text { reduced growth in } \\
\text { vaccinated unchallenged } \\
\text { birds compared with } \\
\text { unvaccinated } \\
\text { unchallenged controls }\end{array}$ & $\begin{array}{l}\text { Intra-cloacal } \\
\text { administration of } 10^{4} \\
\text { low passage virulent } \\
\text { trophozoites either at } 15 \\
\text { or } 29 \text { days age }\end{array}$ & $\begin{array}{l}\text { All } 28 \text { controls developed fatal } \\
\text { histomoniasis. Only } 4 \text { of } 14 \\
\text { vaccinated birds challenged at } \\
15 \text { days survived, but all } 14 \\
\text { vaccinated birds challenged at } \\
29 \text { days remained clinically } \\
\text { healthy and grew as well as } \\
\text { uninfected controls }\end{array}$ & $\begin{array}{l}\text { (Liebhart et al. } \\
\text { 2010) }\end{array}$ \\
\hline
\end{tabular}

${ }^{\text {a }}$ All studies in this table used natural hosts and incorporated challenge controls or epidemiological comparisons. 
Table 6. Representative comparisons of molecular malaria vaccine designs and their performance in artificially adapted animal models and human trials ${ }^{\mathrm{a}}$

\begin{tabular}{|c|c|c|c|c|c|c|c|}
\hline Vaccine design & $\begin{array}{l}\text { Correlation between animal } \\
\text { model and human results }\end{array}$ & Pathogen and host & Molecular details & Production & Inoculation & Results & Selected citations \\
\hline \multirow[t]{2}{*}{$\begin{array}{l}\text { Sporozoite } \\
\text { recombinant } \\
\text { antigen }\end{array}$} & \multirow[t]{2}{*}{ Weak } & P. berghei in mouse & $\begin{array}{l}\text { CSP repetitive moiety } \\
\left(\mathrm{CS}_{170}\right) \text { conjugated to BSA. }\end{array}$ & $\begin{array}{l}\text { In vitro synthesis of } \\
\text { CSP element }\end{array}$ & $5 \times \mathrm{SC}$ & $\begin{array}{l}\text { Mice challenged with sporozoites } 2 \\
\text { weeks after vaccination. Best } \\
\text { protocol resulted in sterile } \\
\text { immunity in } 7 \text { of } 7 \text { mice }\end{array}$ & (Reed et al. 1996) \\
\hline & & $\begin{array}{l}\text { P. falciparum in } \\
\text { humans }\end{array}$ & $\begin{array}{l}\text { RTS,S fusion protein has } \\
\text { half of CSP \& entire surface } \\
\text { ag of hepB virus }\end{array}$ & $\begin{array}{l}\text { Recombinant ag } \\
\text { from transfected } \\
\text { yeast }\end{array}$ & $3 \times \mathrm{IM}$ & $\begin{array}{l}\text { This recombinant protein was first } \\
\text { described in } 1988 \text {. The best } \\
\text { performing vaccine of this type. } \\
\text { Latest field trials achieved } 1 \text { year } \\
\text { efficacy of } 44 \% \text { in children and } \\
30 \% \text { in infants. Efficacy reduces } \\
\text { over time despite frequent natural } \\
\text { exposure }\end{array}$ & $\begin{array}{l}\text { (Rutgers et al. 1988; } \\
\text { Bejon } \text { et al. 2008; } \\
\text { Agnandji et al. 2012; } \\
\text { Olotu et al. 2013) }\end{array}$ \\
\hline \multirow[t]{2}{*}{$\begin{array}{l}\text { Erythrocyte } \\
\text { stage } \\
\text { recombinant } \\
\text { antigen }\end{array}$} & \multirow[t]{2}{*}{ Poor } & $\begin{array}{l}\text { P. falciparum in } \\
\text { Aotus monkeys }\end{array}$ & Pf MSP-1 & $\begin{array}{l}\text { Recombinant ag } \\
\text { from transfected } \\
\text { E. coli }\end{array}$ & $2 \times I M$ & $\begin{array}{l}\text { Protected } 6 \text { of } 6 \text { monkeys against } \\
\text { uncontrolled parasitaemia } \\
\text { following lethal (for naive } \\
\text { monkeys) IV challenge with } \\
\text { infected erythrocytes, } 7 \text { weeks } \\
\text { after vaccination }\end{array}$ & (Darko et al. 2005) \\
\hline & & $\begin{array}{l}\text { P. falciparum in } \\
\text { humans }\end{array}$ & Pf MSP-1 & As above & $3 \times \mathrm{IM}$ & $\begin{array}{l}\text { Vaccine efficacy }<15 \% \text { in field trial. } \\
\text { Children followed } 6 \mathrm{~m} \text { after last } \\
\text { vaccination }\end{array}$ & (Ogutu et al. 2009) \\
\hline \multirow[t]{2}{*}{$\begin{array}{l}\text { Liver stage } \\
\text { recombinant } \\
\text { antigen }\end{array}$} & \multirow[t]{2}{*}{ Poor } & $\begin{array}{l}\text { P. falciparum in } \\
\text { Aotus monkeys }\end{array}$ & $\begin{array}{l}\text { Pf LSA-3 long synthetic } \\
\text { peptides }\end{array}$ & $\begin{array}{l}\text { Recombinant ag } \\
\text { from transfected } \\
\text { E. coli }\end{array}$ & $3 \times \mathrm{SC}$ & $\begin{array}{l}\text { Protected } 3 \text { of } 3 \text { monkeys against } \\
\text { parasitaemia from IV inoculation } \\
\text { of } P \text {. falciparum sporozoites, } 2 \mathrm{~m} \\
\text { after } 3 \text { rd vaccination }\end{array}$ & (Perlaza et al. 2008) \\
\hline & & $\begin{array}{l}\text { P. falciparum in } \\
\text { humans }\end{array}$ & Pf LSA-NRC & As above & $2 \times \mathrm{IM}$ & $\begin{array}{l}\text { All } 22 \text { volunteers became } \\
\text { parasitaemic after being bitten by } \\
5 \text { infected mosquitoes, } 2 \text { weeks } \\
\text { after } 2 \text { nd vaccination }\end{array}$ & (Cummings et al. 2010) \\
\hline \multirow[t]{2}{*}{$\begin{array}{l}\text { DNA using } \\
\text { plasmids \& } \\
\text { live virus }\end{array}$} & \multirow[t]{2}{*}{ Poor } & $\begin{array}{l}P . \text { knowlesi in } \\
\text { rhesus monkeys }\end{array}$ & $\begin{array}{l}4 \mathrm{Pk} \text { ag } \& 3 \text { cytokines } \\
\text { encoded in plasmids, } \\
\text { followed by live virus } \\
\text { bearing the same } \mathrm{Pk} \text { ag }\end{array}$ & $\begin{array}{l}\text { Plasmid vectors } \\
\& \text { genetically } \\
\text { modified live } \\
\text { Vaccinia virus }\end{array}$ & $\begin{array}{l}\text { Plasmid mix } \\
4 \times \text { IM, then } \\
\text { virus mix IM }\end{array}$ & $\begin{array}{l}\text { Infectious challenge } 2 \text { weeks after } \\
\text { viral boost. All } 4 \text { unvaccinated } \\
\text { monkeys were treated for } \\
\text { overwhelming parasitaemia. Of } 11 \\
\text { vaccinated monkeys, sterile } \\
\text { immunity occurred in } 2 \text { and } \\
\text { spontaneous resolution of } \\
\text { parasitaemia occurred in } 7\end{array}$ & (Rogers et al. 2002) \\
\hline & & $\begin{array}{l}\text { P. falciparum } \\
\text { in humans }\end{array}$ & $\begin{array}{l}\text { Pf ME-TRAP in plasmid, } \\
\text { followed by live virus with } \\
\text { same ag. Or identical } \\
\text { regimen substituting CS } \\
\text { moieties for ME-TRAP }\end{array}$ & As above & $\begin{array}{l}\text { Plasmid } \\
2 \times \text { IM, then } \\
\text { virus ID }\end{array}$ & $\begin{array}{l}7 \text { of } 8 \text { volunteers develop } \\
\text { parasitaemia after being bitten by } \\
5 \text { infected mosquitoes, } 2 \text { weeks } \\
\text { following last vaccination with } \\
\text { ME-TRAP. Parasitaemia was } \\
\text { delayed } 1 \text { day. CS vaccine regimen } \\
\text { had no protective effect }\end{array}$ & (Dunachie et al. 2006) \\
\hline
\end{tabular}

a To date, no protozoal vaccine based on these or similar molecular designs has achieved widespread success in humans or animals. 
Giardia lamblia and Tritrichomonas foetus are strictly extracellular parasites.

Tables 1-4 provide examples of the types of protozoal vaccines that are in current use or have been in recent distribution.

\section{Human immunizations}

Leishmanization. Old World and New World forms of cutaneous leishmaniasis are similar conditions caused by different species of Leishmania, which are transmitted by the bite of various phlebotomine sandflies. Infected bites may develop into chronic, ulcerated wounds (Ameen, 2010). Although most lesions ultimately resolve, disfiguring scars may result which can be particularly distressing when they occur on the face. Leishmanization is a controlled-exposure type of immunizing procedure that has been used to protect against cutaneous leishmaniasis (Table 1). Similar procedures were developed and used by several governments in the Middle East and central Asia, and related natural exposure practices (to sandflies) had been in prior use. In Iran, live virulent trophozoites of Leishmania major were produced by intraperitoneal mouse passage followed by limited axenic passage in broth (Nadim et al. 1983). The fresh live inoculum was administered intradermally or by scarification at a site in an arm or shoulder. If the procedure was a 'take', then a cutaneous lesion would develop at the inoculation site. This wound could endure months and in some cases longer than a year before healing with a scar. Immunized individuals were protected from disfiguring scars on the face that may result from natural exposure to L. major-infected sandfly vectors.

Quality assurance of these biological products was difficult. Adverse events were reported, most notably including persistent sores. Despite these problems, leishmanization was credited with greater than $80 \%$ reduction of disease prevalence (Nadim et al. 1997). A review by Dunning (2009) reported that leishmanization was recently employed in Uzbekistan.

Malaria fever therapy. To the author's knowledge, no other human protozoal immunizations have achieved widespread use, other than the possible historical inclusion of virulent malaria inoculations for fever therapy of neurosyphilis ('general paralysis of the insane') practiced in the early and mid-20th century. The intention was not to immunize against malaria, but rather to induce a high fever that would kill or control Treponema pallidum and thereby halt or reduce neurological impairment (as reviewed by Kragh, 2010) . Case reports have been compiled and examined for the effect upon the course of malaria itself when induced in patients more than one time, but highly varied treatment regimens and the understandable lack of controls make conclusions difficult (Collins and Jeffery, 1999).

\section{Immunization using controlled-exposure and} infection-and-treatment protocols (see Table 1)

A logical improvement upon immunization with virulent organisms without treatment, where the infection is allowed to run its full course (controlled-exposure), is to infect patients with virulent organisms and then administer a prophylactic antimicrobial (infection-and-treatment). This practice is still widely used for East coast fever of cattle, and until recently was a common technique for control of poultry coccidiosis. An infectionand-treatment protocol was also recently used for experimental immunization against human malaria (Roestenberg et al., 2009; Table 5).

East coast fever of cattle. This is an economically important disease in eastern, central and southern regions of Africa. The causative organism is Theileria parva. Regionally varied species, subspecies, or variants of $T$. parva exist for which cross-protection may be poor (reviewed by Uilenberg, 1999). The parasite is transmitted by Rhipicephalus ticks and causes high mortality in Bos taurus cattle, less mortality in Bos indicus cattle, while native species of buffalo appear to be well-adapted natural reservoirs. Organisms transmitted by ticks invade, replicate within, and transform bovine lymphocytes, prior to invading erythrocytes from whence they are ingested by ticks; sexual recombination occurs in the tick prior to forming sporozoites within salivary glands.

These organisms are difficult to cultivate in vitro and reliable attenuation has not been achieved. Virulent seed stock organisms are used to infect cattle in the vaccine production process, which are then used to infect ticks. Organisms are harvested from tick salivary glands and are semiquantified, may be cryopreserved, and are used to immunize cattle in the field. Cattle are protected from disease by simultaneous injection of a long-acting formulation of oxytetracycline (Radley et al. 1975). Efficacy of this infection-and-treatment protocol is high and protection endures at least 3 years, but sterile immunity is not achieved. Immunized animals develop a carrier state with potential to transmit virulent organisms to ticks.

A multivalent vaccine (the Mugaga cocktail) (Patel et al. 2011), originally developed by the East African Veterinary Research Organization (now the Kenya Agriculture Research Institute), is licensed and being produced by a commercial enterprise for distribution in Kenya, Tanzania and Malawi (GALVmed, 2010). Different vaccine seed stocks are used in other regions. It is possible to immunize cattle 
in Zimbabwe using low-titration doses of the Boleni stock of $T$. parva without concurrent administration of antibiotics, attributed to its lower virulence (Latif and Hove, 2011).

The life cycle of the parasites of bovine theilerioses shares certain generalized features with that of malaria parasites, including sexual reproduction within a haematophagous arthropod vector, initial invasion within nucleated cells of the vertebrate host, and subsequent invasion of erythrocytes (Marquardt et al. 2000). Furthermore, infection-and-treatment protocols using the corresponding sporozoites induce protection against each of these diseases (Radley et al. 1975; Roestenberg et al. 2009).

Poultry coccidiosis. Eimeria spp. are coccidia of major economic importance to poultry industries around the world. These fecal-oral pathogens have a direct life cycle. Oocysts are excreted in feces and sporulate upon exposure to air. Ingested oocysts excyst in the gastrointestinal tract to release sporozoites, which invade host enterocytes. Each species undergoes a set number of asexual replication cycles within the intestinal tract, ultimately producing gametocytes that combine sexually and become oocysts (McDougald, 1998).

Live oocysts of various Eimeria spp. are purified from the feces of birds used for vaccine production. On farms, oral inoculation of hatchlings with mixed species of coccidial oocysts is used to induce protective immunity. Today, most if not all live coccidiosis vaccines are recommended to be applied without use of anticoccidial drugs, and thus they rely solely upon the birds' ability to mount an effective immune response before serious superinfections can result from re-exposure to organisms in litter. Nevertheless, organism strains used in live vaccines are selected for their continuing sensitivity to anticoccidial drugs. Although now falling out of favour, a common practice was to vaccinate birds and then add low levels of coccidiostatic drugs to feed or water (i.e. infection-and-treatment) (reviewed by Williams, 2002).

Vaccinal protection from disease results from a combination of vaccine-induced immunity, immunological boosting from environmental re-exposure to vaccinal and wild type organisms, and displacement or dilution of coccidiostat-resistant strains in litter that otherwise may be prevalent (presumably this is in case anticoccidial treatment should become necessary). Because meat-producing birds have such short lifespans, induction of short-term immunity may be all that is required of a vaccine for broilers.

\section{Live attenuated vaccines (see Table 2)}

A superior concept to controlled-exposure or infection-and-treatment strategies, when possible, is to develop vaccines that contain live but attenuated organisms that are unlikely to cause disease. The best performing protozoal vaccines have this design. Vaccinal organisms are sometimes manufactured in vivo, including many babesiosis vaccines and all attenuated coccidiosis vaccines; clearly, those production strategies are unsuitable for adaptation to purely human conditions. However, several attenuated vaccines are produced in vitro, have been attenuated using repeatable methods, and show little evidence of vaccine-associated adverse events; similar designs merit strong consideration for development of protozoal vaccines for human diseases.

Bovine tropical theileriosis. The causative organism, Theileria annulata, is a blood-borne apicomplexan parasite that is transmitted by an arthropod vector (Hyalomma ticks). Disease commonly occurs in highly susceptible $B$. taurus cattle in countries bordering the Mediterranean Sea and extending southward into Sudan and eastward into China and India.

Organisms are transmitted to cattle by ticks to invade, replicate within, and cause clonal expansion of macrophages and lymphocytes, prior to invading erythrocytes from whence they are ingested by other ticks. This species of Theileria is adaptable to in vitro culture within bovine macrophages or lymphoid cells. Many strains have become attenuated simply by prolonged passage in cell culture (Boulter and Hall, 1999; Gubbels et al. 2000). Attenuation has been associated with loss of expression of parasiteinduced matrix metalloproteinases, which hinders systemic dissemination of organisms (Hall et al. 1999). Although vaccine strains may cause cryptic infections, latent organisms are incapable of transmission to ticks (Gubbels et al. 2000).

High rates of vaccine efficacy $(>90 \%)$ and safety (100\%) have been claimed (Zhang, 1997; Boulter and Hall, 1999) with little if any evidence of reversion to virulence. Immunity is cross-protective among strains (Boulter and Hall, 1999). Vaccinal protection endures at least 19 months in the field (Yin et al. 2008), although there is room to question whether the duration of vaccine efficacy might depend upon repeated exposure to infected ticks.

Similar vaccines for Theileria lestoquardi (Theileria hirci) are used in Iran, Iraq and Bulgaria to protect sheep from malignant ovine theileriosis (Hooshmand-Rad, 1985; Lawrence, 1997; Ali et al. 2008).

Toxoplasmosis abortion. An attenuated vaccine prevents Toxoplasma gondii-induced abortion in sheep (Buxton, 1993). This vaccine has been in continuous production since 1988 and is currently marketed in New Zealand and parts of Europe. It contains the S48 strain of $T$. gondii, which lost the ability to transform into the bradyzoite stage during years of twice-weekly 
intraperitoneal passage of tachyzoites in mice - such rapid passage did not allow time for stage conversion to form bradyzoites, and the strain lost this ability (Buxton and Innes, 1995). For the commercial production of the vaccine, the $\mathrm{S} 48$ strain is now maintained in tissue culture.

Ewes are vaccinated once, at least 3 weeks before breeding. Vaccination causes a transient fever and then the infection is cleared, unlike natural infections in which bradyzoites form latent intracellular cysts within brain and muscle. The inability to encyst makes the vaccine acceptable to use in a foodproducing animal; otherwise, vaccine organisms in raw tissues could transmit infections to people and cats.

Vaccinal protection from toxoplasmosis abortion is strong against heterologous challenge with ingested oocysts (Wilkins et al. 1988), which has been tested out to 18 months post vaccination (Buxton et al. 1993). The manufacturer recommends revaccination in 2 years.

There are product warnings against vaccination of ewes during pregnancy, and because toxoplasmosis is a zoonotic disease there are further warnings about accidental human inoculation, particularly of pregnant women or immunosuppressed individuals. The author has been unable to find information to suggest that an adverse event may have occurred in people or that abortions in ewes may have been caused by inadvertent vaccination during pregnancy; this absence of published adverse events, after 25 years of commercial use, suggests (but does not prove) that despite the hypothetical concerns, any risks associated with the vaccine may in fact be minimal.

Bovine babesiosis. Babesia spp. are apicomplexan parasites of erythrocytes that are transmitted by tick vectors. Infection causes a febrile haemolytic disease. Morbidity and mortality can be particularly severe in B. taurus cattle.

Many bovine babesiosis vaccines are currently produced by governmental organizations around the world. Most are produced in vivo within splenectomized calves and contain Babesia bovis, Babesia bigemina, or both species. Many babesiosis vaccines may induce clinical disease; for example, a Cuban vaccine (Alonso et al. 1994) was reported to have a $2 \%$ rate of post-vaccination incidents. Vaccine risks are greater in adults (mirroring natural disease risks), so vaccinations are typically restricted to juveniles. Despite these limitations, babesiosis vaccines have been widely used in tropical and subtropical regions and have greatly reduced the incidence of disease losses (Callow et al. 1997).

A babesiosis vaccine currently in use in Argentina merits special attention because it is produced in vitro within bovine erythrocytes (Mangold et al. 1996), although it is not the only babesiosis vaccine to be cultured in this way (reviewed by Shkap and Pipano,
2000). Millions of doses of the combined B. bovis $B$. bigemina vaccine have been used in Argentina, with failure of protection documented in $0.09 \%$ of vaccinated cattle (Echaide, 2008). The B. bovis fraction is known to have lost the ability to be transmitted to tick vectors.

In Europe, bovine babesiosis is caused by Babesia divergens, and vaccines have been produced for that pathogen (reviewed by Bock et al. 2008; Zintl et al. 2003). Many methods of attenuation and production were reported including in vivo within splenectomized calves and also within Mongolian gerbils (Meriones unguiculatas), or in vitro within erythrocytes. The use of gerbils for vaccine production was thought to have biosecurity and safety advantages over use of calves, however no more than 200 vaccine doses could be generated from a single gerbil. The apparent paucity of $B$. divergens vaccines available at present may have been influenced in part by the bovine spongiform encephalopathy epidemic in Europe and heightened concerns about disease transmission risks of bovine biological products.

An attenuated vaccine for Babesia ovis has been used to protect sheep in Bulgaria (Lawrence, 1997).

Precocious coccidiosis vaccines. An alternative to infection-and-treatment coccidiosis immunization protocols is the use of attenuated vaccines. The elegant 'precocious' method of attenuation was first described for Eimeria tenella (Jeffers, 1975), and the same method has been effectively applied to multiple species of poultry coccidia. Precocious strains of Eimeria spp. are selected by collecting the earliest forming oocysts from each infection, using those oocysts to infect the next subject, collecting the earliest oocysts again, and so on for multiple generations. Prepatent periods become shortened; this effect can be the result of the loss of one or more asexual cycles in the intestinal tract prior to gametogony (McDougald and Jeffers, 1976), or by a shortening of the time that each schizont takes to develop, and/or by a reduction in the size of schizonts and number of progeny within them (McDonald and Shirley, 2009).

Reduced asexual reproduction of precocious strains in the intestinal tract leads to less mucosal damage, fewer oocysts produced, and a corresponding reduction in the number of oocysts that accumulate in the environment (McDonald and Shirley, 2009). A manufacturing drawback is that because fewer precocious oocysts are produced in comparison with wild-type infections, a greater number of birds must be used for in vivo production of vaccinal oocysts and this increases production costs.

Precocious attenuation is a repeatable achievement and many stable strains have been developed. The prototype Wis-F strain of E. tenella could not be induced to revert to a longer prepatent period or 
virulence even when it was subjected to a relaxed selection protocol for 25 generations (Jeffers, 1975).

The precocious selection concept has recently been adapted to create Eimeria spp. vaccine strains for rabbits (Pakandl, 2005; Akpo et al. 2012), although it is unclear whether any have progressed to commercial use or regional distribution.

Vaccines containing whole killed protozoa (see Table 3)

Only four examples were found of commercially marketed protozoal vaccines containing whole killed organisms. All of these vaccines incorporate adjuvants and require two initial immunizations. Although these products are safe, they induce at best only partial protection for a brief period of time. However, even brief protection may have useful niche applications, such as vaccination prior to the breeding season to reduce a sexually transmitted disease of cattle (trichomoniasis). Two of these products have been withdrawn from the market.

\section{Vaccines containing subunit antigens (see Table 4)}

Only a few examples were found of commercially marketed protozoal vaccines based on defined or extracted antigens. All of the products in this class can be referred to as subunit vaccines; however, most of them are not recombinant antigen vaccines, because the vaccinal antigens are not derived from artificial synthesis or from transfection of other organisms such as bacteria, yeast, insect cells or viral vectors. All subunit protozoal vaccines incorporate adjuvants and require two or three initial immunizations.

Evidence of field efficacy has been published for two subunit protozoal vaccines (Leishmune and Coxabic). Unfortunately, the single example of a true recombinant antigen vaccine (Leish-Tec) has no documentation of field efficacy (from PubMed and Google searches or from the manufacturer's website).

Canine visceral leishmaniasis. Dogs and other canids are important reservoir hosts of Leishmania infantum, one of the pathogens of visceral leishmaniasis (canine and human). The pathogen is transmitted by sandflies when obtaining blood meals. In Brazil, a commercial vaccine for dogs (Leishmune) contains Fucose-Mannose-Ligand glycoprotein antigen derived from axenic culture of $L$. donovani (not L. infantum), administered with saponin adjuvant. This antigen complex plays a role in the entry of parasites into host phagocytes, a prerequisite for parasite replication and trafficking.

In field trials, vaccination with Leishmune reduced the incidence of disease in dogs over several years (Borja-Cabrera et al. 2002; Nogueira et al. 2005). Importantly, experimental evidence indicates that the vaccine helps to block transmission of $L$. infantum from dogs to sandfly vectors (Saraiva et al. 2006). These properties are consistent with epidemiological evidence associating vaccination of dogs with statistically significant reductions of human visceral leishmaniasis (Palatnik-de-Sousa et al. 2009).

In addition to vaccination of dogs, public health programmes in Brazil include identification and removal of Leishmania-infected dogs. This complicates epidemiological analysis, so further, publicsponsored investigations are merited to more clearly distinguish between the degree of human protection that is attributable to vaccination of dogs and to culling of infected dogs, respectively.

A similar Leishmania vaccine for dogs (CaniLeish) has been provisionally licensed in parts of Europe (EMA, 2011). The vaccine contains Excreted Secreted Proteins (ESP) of L. infantum. Pre-licensing experiments, using ESP in muramyl dipeptide as adjuvant, demonstrated protection from infectious challenge for at least 8 months (Lemesre et al. 2005), and a double-blind field trial of approximately 400 dogs showed $92 \%$ efficacy in preventing infections over a 2 -year period (Lemesre et al. 2007). The provisionally licensed formulation of CaniLeish contains saponin adjuvant instead of muramyl dipeptide.

A third vaccine for canine leishmaniasis, licensed in Brazil since 2007 (Leish-Tec), is perhaps the only marketed recombinant antigen vaccine for any protozoal disease. It contains a Leishmania amastigote antigen (A2) purified from transfected Escherichia coli. A small trial showed partial shortterm protection of vaccinated dogs from a severe infectious challenge (Fernandes et al. 2008). There appear to be no further published investigations of efficacy.

Coccidiosis of chickens. A subunit vaccine containing two native antigens extracted from Eimeria maxima macrogametocytes is marketed for vaccination of hens to provide passive immunization of chicks (Coxabic) (reviewed by Sharman et al. 2010). Organisms used in vaccine production are produced in vivo in chickens and are extracted from the intestinal tract. Maternal antibody is passed via the egg to hatchlings.

Passive immunity engendered by Coxabic is sufficient to enable offspring to perform well and to transition towards active immunity against mixed Eimeria spp. as a result of ubiquitous natural exposure. Vaccine efficacy has also been inferred from production data of large-scale field trials in which growth and mortality were similar between the offspring of vaccinated hens and the offspring of unvaccinated hens in which coccidiosis had been managed using traditional industry practices (i.e. prophylactic coccidiostatic drugs in feed, and/or use of live vaccines) (Wallach et al. 2008). Because of its 
manner of production and application, Coxabic is more expensive per dose than are other types of coccidiosis vaccines, however each vaccinated hen passes immunity to numerous offspring.

Canine babesiosis. A vaccine for canine babesiosis, containing soluble protein antigens derived from in vitro cultures of Babesia canis and Babesia rossi, was demonstrated to ameliorate the severity of infectious challenge with heterologous $B$. canis for up to 6 months after vaccination (Schetters et al. 2001, 2006). The infectious challenge in these experiments was severe, having been induced by intravenous inoculation of infected erythrocytes rather than by the bite of infected ticks; infectious challenge experiments that are overly harsh have the potential to mask the protective effect of a vaccine. In these experiments, haematocrit values dropped 54\% in vaccinated dogs compared with a $65 \%$ drop in unvaccinated controls, and clinical scores also showed modest but statistically significant improvements (Schetters et al. 2006).

The vaccine was marketed in parts of Europe, but unfortunately there was no published epidemiological study and the product is no longer in production. Therefore, it is unclear whether the vaccine may have prevented or reduced transmission from ticks, or if the effects were limited to a reduction in the severity of disease as in the challenge experiments.

\section{Comparisons across vaccine classes}

Propagation of organisms. Perhaps the single most obvious conclusion is that the production of all effective protozoal vaccines is dependent upon growth of protozoal organisms, either in vitro or in vivo; this includes production of organisms within arthropod vectors. Effective vaccines don't always contain whole organisms, but even native subunit vaccines require culture of organisms for extraction of antigens. The author has found only one commercially available recombinant antigen vaccine, but no evidence has been published to support the efficacy of that vaccine in the field. There are no licensed protozoal vaccines based on DNA or viral vectors.

This conclusion has a profound implication: for any protozoal disease to be controlled by a vaccine, methods must be developed to cultivate the pathogen. Although breaking this paradigm is a legitimate goal of protozoal vaccine science, vaccine designs with this goal carry a high risk of failure.

The value of living organisms. A single inoculation of living organisms, whether virulent or attenuated, tends to create strong, long-lasting protection against most protozoal diseases. The advantage of great efficacy is tempered by legitimate safety concerns, even though many attenuated vaccines have excellent safety records. A major rationale for research of novel protozoal vaccine designs for human diseases has been that live vaccines carry unacceptable risks; however, while many novel vaccines have been safe they have not been effective. Moving forward, new emphasis should be placed upon the development of novel methods to improve the safety of live vaccines, which can reasonably be expected to be effective.

Uses for short-term protection. Killed and subunit vaccines require adjuvants, booster inoculations, and annual or semiannual revaccination. The relatively short duration of protection is a disadvantage. However, residents of highly endemic regions may only need vaccinal immunity in the short term, and then naturally acquired immunity could take over as a result of frequent natural exposure. An example of this is vaccination of hens to provide passive protection of chicks from coccidiosis (Sharman et al. 2010).

Mucosal vaccines. In relation to mucosal pathogens, the endurance of effective immunity that may be attributed solely to live vaccination is unclear and is worthy of further research. For example, the true duration of effective immunity resulting solely from application of a poultry coccidiosis vaccine is obscured by the daily natural exposure of production birds to coccidia in litter (Williams et al. 2000). Although this distinction may be unimportant for the control of coccidiosis in poultry, the duration of protection of mucosal vaccines in the absence of frequent endemic exposure is an important consideration for development of future veterinary or human vaccines against diseases such as giardiasis, cryptosporidiosis, amoebiasis, microsporidiosis and trichomoniasis.

Parenteral vaccination with killed mucosal pathogens appears to provide modest, short-lived protection at most, and has been inadequately investigated (Lehmann and Lehmann, 2004; Baltzell et al. 2013).

\section{EXPERIMENTAL PROTOZOAL VACCINES}

\section{Experimental vaccines containing organisms}

Table 5 gives details of several noteworthy vaccination experiments that, although often highly effective, have not (or have not yet) resulted in a marketed vaccine. All of these experiments were based on live, attenuated, or whole-killed protozoal organisms. The results of these studies carry great predictive value because each was performed using a natural host-parasite relationship.

Two human malaria trials show protective efficacy for infection-and-treatment (Roestenberg et al. 2009) and whole-organism protocols (Seder et al. 2013); these experimental immunization protocols have counterparts among veterinary vaccines, and closely 
analogous experiments using avian malaria essentially predicted these results as much as a century earlier (Sergent and Sergent, 1910; Richards, 1966). Although an intravenously administered irradiated vaccine, recently examined by Seder et al. (2013), is described as being metabolically active, the experimental results compare closely with killed vaccines investigated in chickens (Richards, 1966). These investigations need to be progressed further, to include heterologous infectious challenges at meaningfully long intervals after immunization.

An attenuated vaccine to prevent cats from disseminating $T$. gondii oocysts was a remarkable scientific success but was not commercially viable. The vaccine was designed to reduce transmission from cats to other animals and humans. The T-263 strain of $T$. gondii was developed by chemical mutagenesis and selection for the inability to undergo sexual recombination (Frenkel et al. 1991). The orally administered vaccine demonstrated high efficacy in infectious challenge experiments of cats (Frenkel et al. 1991; Freyre et al. 1993). Additionally, in an ambitious 3-year field trial, cats were trapped and vaccinated on swine farms. The number of cats observed to be shedding oocysts and the $T$. gondii seroprevalence of pigs and rodents on farms decreased significantly (Mateus-Pinilla et al. 1999), consistent with decreased oocyst contamination of farms. Although effective, this vaccine would have been expensive to manufacture and distribute, and difficult to market.

Field evidence was obtained for efficacy of a vaccine to prevent human cutaneous leishmaniasis in Ecuador, which contained three local isolates of Leishmania spp. promastigotes that were phenolkilled and administered with BCG adjuvant. Vaccinated and control subjects were monitored for a year, and cutaneous leishmaniasis occurred in $2 \%$ and $8 \%$, respectively (Armijos et al. 1998). The vaccine required a booster and annual revaccination (Armijos et al. 2003). Injection site swelling and mild fever were frequently observed especially following the second application; this could have been caused by reaction to Leishmania spp. antigens or to the BCG adjuvant. The vaccine does not appear to have been brought forward for commercial or governmental use. Another killed vaccine for human cutaneous leishmaniasis was recently trialled in Brazil and positive results were reported (Mayrink et al. 2013).

An attenuated vaccine for histomoniasis of turkeys and chickens has been developed by researchers in Austria. The vaccinal strain became attenuated when organisms were passaged every 2-3 days in axenic broth culture for 295 times. The vaccine is effective when administered into the crop or into the cloaca, and provides strong protection in challenge experiments, at least against low passage virulent organisms of the parent strain (Liebhart et al. 2010, 2013).
Histomoniasis is re-emerging as a cause of poultry losses, in part because the prophylactic use of effective antimicrobials has been restricted or banned. Practical issues to overcome in order to commercialize this type of product will probably include the economics of transportation and administration of cryopreserved vaccines, which must be inexpensive to be used in poultry.

\section{Experimental molecular malaria vaccines}

Table 6 compares results of animal models and human trials for several prominent types of experimental malaria vaccines. Malaria has been the dominant category of protozoal vaccine research in recent history. All of the vaccines in Table 6 were based on novel molecular designs.

In each comparison in Table 6 , the positive results obtained in animal models exceeded the results obtained in humans. The following factors help explain the poor predictive value of those experiments: (1) Reliance upon artificially adapted hostparasite models of malaria; (2) Investigation of unreasonably short intervals between vaccination and infectious challenge experiments; (3) Use of homologous organisms in infectious challenge experiments; (4) Vaccine designs that disregard the history of veterinary protozoal vaccines. These four factors are discussed in greater detail in the following sections.

\section{The importance of animal model selection}

All of the animal malaria models in Table 6 are artificial combinations of host and parasite. Natural malarias have a period of acute illness, during which mortality may occur in a minority of individuals, typically followed by recovery with prolonged splenomegaly, frequent development of latent infections, and the possibility of disease relapse (Garnham, 1966; Miller et al. 1994). Metaphorically, there is a standoff between host and parasite rather than absolute victory for either one. In contrast, artificially adapted malaria models tend to behave in a 'winner-takes-all' manner that does not resemble naturally evolved malaria relationships.

Laboratory rodent-adapted Plasmodium spp. are natural parasites of Thamnomys and Grammomys spp. of thicket rats (Vincke and Lips, 1948; Cox, 1988), native to montane forests of central Africa. The ancestral lineage of these rodents diverged from that of the house mouse over 10 million years ago (Lecompte et al. 2008). The natural hosts are well adapted and do not suffer high mortality (Garnham, 1980). In contrast, experimental malaria in laboratory mice has high mortality, with many mouse-parasite combinations being completely lethal. Rescue of infected mice tends to cause sterile recovery 
(i.e. without chronic or latent infections) (Ishih et al. 2013). This is a winner-takes-all scenario.

Natural hosts of Plasmodium knowlesi include longtailed macaques (Macaca fascicularis) and pig-tailed macaques (Macaca nemestrina), in which the results of infection are variable and have low mortality (Butcher et al. 2010). Rhesus monkeys (Macaca mulatta) are not natural hosts of $P$. knowlesi, and infection in them induces fulminating parasitaemia usually resulting in death (Collins, 1988), similar to Plasmodium berghei infection of mice. This is another winner-takes-all scenario.

Infection of owl monkeys (Aotus spp.) with the human pathogen Plasmodium falciparum creates another winner-takes-all scenario (Sadun et al. 1969).

In artificial winner-takes-all relationships, relatively minor treatments may cause a radical shift between the only two major outcomes, death or sterile recovery. Researchers may mistakenly believe that lethal models of malaria are severe tests for any vaccine, and that survival after vaccination is therefore evidence of great efficacy. In practice, a vaccine that reduces infection or moderates disease in any naturally evolved host-parasite relationship is more predictive of what may be expected in other animals with similar parasites, presumably including humans. A vaccine that ameliorates the course of naturally evolved malarias in Thamnomys rodents, pig-tailed macaques, canaries, or chickens, should be expected to have greater predictive value for human malaria than do vaccines that block mortality in mice, owl monkeys, or in other artificially adapted animal models.

\section{Short testing intervals}

Data for the protective efficacy of most vaccines should be assessed over a range of intervals that extend into a useful duration. Short-lived immunity may be adequate for poultry coccidiosis or seasonal breeding of cattle; however, vaccines for systemic illnesses such as malaria should be tested at least to 6 months, and preferably to a year or more.

\section{Homologous vs heterologous infectious challenge}

To be effective in the field, vaccines need to protect against a variety of organism isolates. When possible, vaccines should be tested by challenge with heterologous organisms, rather than with the same strain from which the vaccine was manufactured. Research efforts should include acquisition of varied isolates for any pathogen under investigation. Ultimately, efficacy must be assessed in field trials within endemic regions.

\section{Vaccine designs that are useful in animals}

There is a reason why veterinary medicine hasn't created a bevy of recombinant antigen vaccines for the prevention of protozoal diseases of animals - they haven't been sufficiently effective.

This is not to imply that such vaccine designs could never work, or that transformational new knowledge will never open a floodgate of effective vaccines based on novel technological advancements. Potentially transformative but technologically difficult and unproven vaccine designs should be investigated first in naturally occurring diseases of animals, not in artificial models. Translation of a novel design principle to human vaccines should be attempted after it has been shown to be effective against a natural animal-parasite relationship. If science cannot create an effective recombinant antigen or plasmid vaccine to prevent infection of (for example) rats with T. gondii, deer mice with Babesia microti, or sparrows with Plasmodium relictum, then it seems rather naive to expect such designs to be effective against human protozoal diseases.

Funding for veterinary medical research is paltry in comparison to human disease research. Human medical research agencies should fund research of protozoal diseases of animals in order to develop improved vaccine methods and investigate new paradigms. At the same time, protozoal vaccines for people should be developed by adapting currently effective techniques from veterinary medicine.

\section{ONE MEDICINE}

The concept of 'One Medicine' includes the beneficial flow of knowledge and techniques from human medicine to veterinary medicine, and from veterinary medicine to human medicine. However, because of the dominance of human medical research funding, the flow of information moves predominantly from human medicine to veterinary medicine. Human medicine is missing significant benefits that could be had by paying greater attention to veterinary knowledge and by supporting opportunities to investigate naturally occurring diseases of animals. This missed opportunity is vividly illustrated by the discordance between development of veterinary protozoal vaccines, of which there are many, and human protozoal vaccines, of which there are none.

\section{REFERENCES}

Agnandji, S. T., Lell, B., Fernandes, J. F., Abossolo, B. P., Methogo, B. G., Kabwende, A. L., Adegnika, A. A., Mordmuller, B., Issifou, S., Kremsner, P. G., Sacarlal, J., Aide, P., Lanaspa, M., Aponte, J. J., Machevo, S., Acacio, S., Bulo, H., Sigauque, B., Macete, E., Alonso, P., Abdulla, S., Salim, N., Minja, R., Mpina, M., Ahmed, S., Ali, A. M., Mtoro, A. T., Hamad, A.S., Mutani, P., Tanner, M. et al. (2012). A phase 3 trial of RTS,S/AS01 malaria vaccine in African infants. New England Fournal of Medicine 367, 2284-2295. doi: 10.1056/NEJMoa1208394.

Akpo, Y., Kpodekon, M. T., Djago, Y., Licois, D. and Youssao, I. A. (2012). Vaccination of rabbits against coccidiosis using precocious lines of Eimeria magna and Eimeria media in Benin. Veterinary Parasitology 184 73-76. doi: 10.1016/j.vetpar.2011.08.012. 
Ali, A. M., Beyer, D., Bakheit, M. A., Kullmann, B., Salih, D. A., Ahmed, J. S. and Seitzer, U. (2008). Influence of subculturing on gene expression in a Theileria lestoquardi-infected cell line. Vaccine $\mathbf{2 6}$ (Suppl. 6), G17-G23. doi: 10.1016/j.vaccine.2008.10.009

Alonso, M., Blandino, T., Mendoza, E., Savon, L. and Camacho, M. (1994). Development of a Babesia bovis live attenuated vaccine. Archivos de Medicina Veterinaria 25, 273-277.

Ameen, M. (2010). Cutaneous leishmaniasis: advances in disease pathogenesis, diagnostics and therapeutics. Clinical and Experimental Dermatology 35, 699-705. doi: 10.1111/j.1365-2230.2010.03851.x

Armijos, R.X., Weigel, M. M., Aviles, H., Maldonado, R. and Racines, J. (1998). Field trial of a vaccine against New World cutaneous leishmaniasis in an at-risk child population: safety, immunogenicity, and efficacy during the first 12 months of follow-up. Fournal of Infectious Diseases 177, 1352-1357

Armijos, R. X., Weigel, M. M., Romero, L., Garcia, V. and Salazar, J. (2003). Field trial of a vaccine against new world cutaneous leishmaniasis in an at-risk child population: how long does protection last? Fournal of Infectious Diseases 187, 1959-1961. doi: 10.1086/375399.

Baltzell, P., Newton, H. and O'Connor, A. M. (2013). A critical review and meta-analysis of the efficacy of whole-cell killed Tritrichomonas foetu vaccines in beef cattle. Fournal of Veterinary Internal Medicine 27, 760-770. doi: $10.1111 /$ jvim. 12112

Bejon, P., Lusingu, J., Olotu, A., Leach, A., Lievens, M., Vekemans, J., Mshamu, S., Lang, T., Gould, J., Dubois, M. C., Demoitie, M. A., Stallaert, J. F., Vansadia, P., Carter, T., Njuguna, P., Awuondo, K. O. Malabeja, A., Abdul, O., Gesase, S., Mturi, N., Drakeley, C. J., Savarese, B., Villafana, T., Ballou, W. R., Cohen, J., Riley, E. M., Lemnge, M. M., Marsh, K. and von Seidlein, L. (2008). Efficacy of RTS,S/AS01E vaccine against malaria in children 5 to 17 months of age. New England Fournal of Medicine 359, 2521-2532. doi: NEJMoa0807381 [pii] 10.1056/NEJMoa0807381.

Bock, R. E. and de Vos, A. J. (2001). Immunity following use of Australian tick fever vaccine: a review of the evidence. Australian Veterinary fournal 79 832-839.

Bock, R. E., Jorgensen, W. K. and Molloy, J. B. (2008). Bovine babesiosis. In Manual of Diagnostic Tests and Vaccines for Terrestria Animals (Mammals, Birds, and Bees), Vol. 2, pp. 611-623. Office International des Epizooties, Paris, France.

Borja-Cabrera, G.P., Correia Pontes, N. N., da Silva, V.O., Paraguai de Souza, E., Santos, W. R., Gomes, E. M., Luz, K. G., Palatnik, M. and Palatnik de Sousa, C. B. (2002). Long lasting protection against canine kala-azar using the FML-QuilA saponin vaccine in an endemic area of Brazil (Sao Goncalo do Amarante, RN). Vaccine 20 3277-3284.

Boulter, N. and Hall, R. (1999). Immunity and vaccine development in the bovine theilerioses. Advances in Parasitology 44, 41-97.

Butcher, G. A., Mitchell, G. H. and Cohen, S. (2010). Plasmodium knowlesi infections in a small number of non-immune natural hosts (Macaca fascicularis) and in rhesus monkeys (M. mulatta). Transactions of the Royal Society of Tropical Medicine and Hygiene 104, 75-77. doi: 10.1016/j. trstmh.2009.05.017.

Buxton, D. (1993). Toxoplasmosis: the first commercial vaccine. Parasitology Today 9, 335-337.

Buxton, D. and Innes, E. A. (1995). A commercial vaccine for ovine toxoplasmosis. Parasitology 110 (Suppl.), S11-S16.

Buxton, D., Thomson, K. M., Maley, S., Wright, S. and Bos, H. J. (1993). Experimental challenge of sheep 18 months after vaccination with a live (S48) Toxoplasma gondii vaccine. Veterinary Record 133, 310-312.

Callow, L. L., Dalgliesh, R. J. and de Vos, A. J. (1997). Development of effective living vaccines against bovine babesiosis - the longest field trial? International Fournal for Parasitology 27, 747-767.

Choromanski, L. and Block, W. (2000). Humoral immune responses and safety of experimental formulations of inactivated Neospora vaccines. Parasitology Research 86, 851-853.

Cobo, E. R., Morsella, C., Cano, D., Cipolla, A. and Campero, C. M. (2004). Immunization in heifers with dual vaccines containing Tritrichomonas foetus and Campylobacter fetus antigens using systemic and mucosal routes. Theriogenology 62, 1367-1382.

Collins, W. E. (1988). Major animal models in malaria research: simian. In Malaria Principles and Practice of Malariology, Vol. II (ed. Wernsdorfer, W. H. and McGregor, I.), pp. 1473-1501. Churchill Livingstone, Edinburgh, UK.

Collins, W. E. and Jeffery, G. M. (1999). A retrospective examination of secondary sporozoite- and trophozoite-induced infections with Plasmodium falciparum: development of parasitologic and clinical immunity following secondary infection. American Fournal of Tropical Medicine and Hygiene 61 (1 Suppl.), 20-35.
Cornelissen, A.W. and Schetters, T.P. (1996). Vaccines against protozoal diseases of veterinary importance. FEMS Immunology and Medical Microbiology 15, 61-72.

Cox, F.E. G. (1988). Major animal models in malaria research: rodent In Malaria Principles and Practice of Malariology, Vol. 2 (ed. Wernsdorfer, W. H. and McGregor, I.), pp. 1503-1543. Churchill Livingstone, Edinburgh, UK.

Cummings, J. F., Spring, M. D., Schwenk, R. J., Ockenhouse, C. F. Kester, K. E., Polhemus, M. E., Walsh, D. S., Yoon, I. K., Prosperi, C., Juompan, L.Y., Lanar, D. E., Krzych, U., Hall, B. T., Ware, L. A., Stewart, V. A., Williams, J., Dowler, M., Nielsen, R. K., Hillier, C. J., Giersing, B. K., Dubovsky, F., Malkin, E., Tucker, K., Dubois, M. C., Cohen, J. D., Ballou, W. R. and Heppner, D. G., Jr. (2010). Recombinan Liver Stage Antigen-1 (LSA-1) formulated with AS01 or AS02 is safe, elicits high titer antibody and induces IFN-gamma/IL-2 CD4 + T cells bu does not protect against experimental Plasmodium falciparum infection. Vaccine 28, 5135-5144. doi: 10.1016/j.vaccine.2009.08.046.

Darko, C. A., Angov, E., Collins, W.E., Bergmann-Leitner, E.S. Girouard, A. S., Hitt, S. L., McBride, J. S., Diggs, C. L., Holder, A. A. Long, C. A., Barnwell, J. W. and Lyon, J. A. (2005). The clinical-grade 42-kilodalton fragment of merozoite surface protein 1 of Plasmodium falciparum strain FVO expressed in Escherichia coli protects Aotus nancymai against challenge with homologous erythrocytic-stage parasites. Infection and Immunity 73, 287-297. doi: 10.1128/IAI.73.1.287-297.2005.

Di Giulio, G., Lynen, G., Morzaria, S., Oura, C. and Bishop, R. (2009) Live immunization against East Coast fever - current status. Trends in Parasitology 25, 85-92. doi: 10.1016/j.pt.2008.11.007.

Dunachie, S. J., Walther, M., Epstein, J. E., Keating, S., Berthoud, T., Andrews, L., Andersen, R. F., Bejon, P., Goonetilleke, N., Poulton, I. Webster, D. P., Butcher, G., Watkins, K., Sinden, R. E., Levine, G. L., Richie, T. L., Schneider, J., Kaslow, D., Gilbert, S. C., Carucci, D. J. and Hill, A. V. (2006). A DNA prime-modified vaccinia virus Ankara boost vaccine encoding thrombospondin-related adhesion protein but not circumsporozoite protein partially protects healthy malaria-naive adults against Plasmodium falciparum sporozoite challenge. Infection and Immunity 74, 5933-5942 doi: 10.1128/IAI 00590-06.

Dunning, N. (2009). Leishmania vaccines: from leishmanization to the era of DNA technology. Bioscience Horizons 2, 73-82.

Echaide, I. E. (2008). Bovine babesiosis: vaccines [Babesiosis dos bovinos: vacinas]. In $X V$ Congresso Brasileiro de Parasitologia Veterinária. Instituto Nacional de Tecnología Agropecuraria, Curitaba, Parana, Brasil.

EMA (2011). European Medicines Agency, Scientific discussion of CaniLeish. http://www.ema.europa.eu/docs/en_GB/document_library/ EPAR_-_Public_assessment_report/veterinary/002232/WC500104953. pdf.

Fernandes, A. P., Costa, M. M., Coelho, E. A., Michalick, M.S., de Freitas, E., Melo, M. N., Luiz Tafuri, W., Resende Dde, M., Hermont, V., Abrantes Cde, F. and Gazzinelli, R. T. (2008) Protective immunity against challenge with Leishmania (Leishmania) chagasi in beagle dogs vaccinated with recombinant A2 protein. Vaccine 26, 5888-5895. doi: 10.1016/j.vaccine.2008.05.095.

Frenkel, J. K., Pfefferkorn, E. R., Smith, D. D. and Fishback, J. L. (1991). Prospective vaccine prepared from a new mutant of Toxoplasma gondii for use in cats. American fournal of Veterinary Research 52, 759-763. Freyburger, L., Lemaitre, L., Medaille, C., Oberli, F., Fanchon, L. and Bergamo, P. (2011). [Comparative safety study of two commercialised vaccines against canine babesiosis induced by Babesia canis]. Parasite 18 311-318.

Freyre, A., Choromanski, L., Fishback, J. L. and Popiel, I. (1993) Immunization of cats with tissue cysts, bradyzoites, and tachyzoites of the T-263 strain of Toxoplasma gondii. Fournal of Parasitology 79, 716-719. GALVmed (2010). GALVmed and East Coast Fever. November Newsletter. http://www.galvmed.org/newsletter-november-2010-galvmedand-east-coast-fever/.

Garnham, P. C. C. (1966). II. Life cycle and morphology. In Malaria Parasites and Other Haemosporidia, pp. 17-59. Blackwell Scientific, Oxford, UK.

Garnham, P. C. C. (1980). Malaria and its various vertebrate hosts. In Malaria, Vol. 1, (ed. Kreier, J. P.), pp. 95-144. Academic Press, New York, NY, USA.

Gerdts, O. V. and Ortíz, E. B. (2004). Vacuna Colombiana contra anaplasmosis y babesiosis bovinas: la alternativa más eficaz y económica para el control de estos hemoparasitismos. http://www.cundinamarca.gov.co/ cundinamarca/archivos/FILE_EVENTOSENTI/FILE_EVENTOSEN'T I11832.pdf

Gruber, M.F. (2011). US FDA review and regulation of preventive vaccines for infectious disease indications: impact of the FDA Amendments Act 2007. Expert Review of Vaccines 10, 1011-1019. doi: 10.1586/erv.11.52. 
Gubbels, M. J., Viseras, J., Habela, M. A. and Jongejan, F. (2000). Characterization of attenuated Theileria annulata vaccines from Spain and the Sudan. Tropical Veterinary Diseases 916, 521-532.

Hall, R., Ilhan, T., Kirvar, E., Wilkie, G., Preston, P. M., Darghouth, M., Somerville, R. and Adamson, R. (1999). Mechanism (s) of attenuation of Theileria annulata vaccine cell lines. Tropical Medicine and International Health 4, A78-A84.

Harp, J. A. and Goff, J. P. (1995). Protection of calves with a vaccine against Cryptosporidium parvum. Fournal of Parasitology 81, 54-57.

Hashemi-Fesharki, R. (1988). Control of Theileria annulata in Iran. Parasitology Today 4, 36-40. doi: 0169-4758(88)90062-2 [pii].

Hooshmand-Rad, P. (1985). The use of tissue culture attenuated live vaccine for Theileria hirci. Developments in Biological Standardization 62, 119-127

Ishih, A., Kawakami, C., Todoroki, A., Hirai, H., Ohori, K. and Kobayashi, F. (2013). Outcome of primary lethal and nonlethal Plasmodium yoelii malaria infection in $\mathrm{BALB} / \mathrm{c}$ and IFN-gamma receptordeficient mice following chloroquine treatment. Parasitology Research 112, 773-780. doi: 10.1007/s00436-012-3197-y.

Jeffers, T. K. (1975). Attenuation of Eimeria tenella through selection for precociousness. Fournal of Parasitology 61, 1083-1090.

Kragh, J. V. (2010). Malaria fever therapy for general paralysis of the insane in Denmark. History of Psychiatry 21 (84 Pt 4), 471-486.

Latif, A. A. and Hove, T. (2011). History and critical review of Theileria parva (Boleni), the vaccine stock against Zimbabwean cattle theileriosis. Ticks and Tick Borne Diseases 2, 163-167. doi: 10.1016/j.ttbdis.2011.06.002. Lawrence, J. A. (1997). Conventional vaccines for tick-borne haemoparasitic diseases of sheep and goats. Parassitologia 39, 119-121.

Lecompte, E., Aplin, K., Denys, C., Catzeflis, F., Chades, M. and Chevret, P. (2008). Phylogeny and biogeography of African Murinae based on mitochondrial and nuclear gene sequences, with a new tribal classification of the subfamily. BMC Evolutionary Biology 8, 199. doi: 1471-2148-8-199 [pii] 10.1186/1471-2148-8-199.

Lehmann, C. and Lehmann, W. (2004). Giardia: infection and vaccination in an animal shelter. Tierarztliche Umschau 59, 337-340.

Lemesre, J. L., Holzmuller, P., Cavaleyra, M., Goncalves, R. B., Hottin, G. and Papierok, G. (2005). Protection against experimental visceral leishmaniasis infection in dogs immunized with purified excreted secreted antigens of Leishmania infantum promastigotes. Vaccine 23, $2825-2840$.

Lemesre, J. L., Holzmuller, P., Goncalves, R. B., Bourdoiseau, G., Hugnet, C., Cavaleyra, M. and Papierok, G. (2007). Long-lasting protection against canine visceral leishmaniasis using the LiESAp-MDP vaccine in endemic areas of France: double-blind randomised efficacy field trial. Vaccine 25, 4223-4234. doi: 10.1016/j.vaccine.2007.02.083.

Liebhart, D., Windisch, M. and Hess, M. (2010). Oral vaccination of 1-day-old turkeys with in vitro attenuated Histomonas meleagridis protects against histomonosis and has no negative effect on performance. Avian Pathology 39, 399-403. doi: 10.1080/03079457.2010.506906.

Liebhart, D., Sulejmanovic, T., Grafl, B., Tichy, A. and Hess, M. (2013). Vaccination against histomonosis prevents a drop in egg production in layers following challenge. Avian Pathology 42, 79-84. doi: 10.1080/ 03079457.2012.760841.

Long, P. L., Millard, B. J., Batty, A.F. and da Vison, C. (1982). Immunisation against coccidiosis in chickens: tests under simulated field conditions. Avian Pathology 11, 131-144. doi: 10.1080/ 03079458208436088

Mangold, A. J., Vanzini, V.R., Echaide, I. E., de Echaide, S. T., Volpogni, M. M. and Guglielmone, A. A. (1996). Viability after thawing and dilution of simultaneously cryopreserved vaccinal Babesia bovis and Babesia bigemina strains cultured in vitro. Veterinary Parasitology 61, 345-348.

Marquardt, W. C., Demaree, R.S. and Grieve, R. B. (eds) (2000). Piroplasmea and piroplasmosis. In Parasitology and Vector Biology, pp. 211-224. Academic Press, San Diego, CA, USA.

Mateus-Pinilla, N.E., Dubey, J.P., Choromanski, L. and Weigel, R. M. (1999). A field trial of the effectiveness of a feline Toxoplasma gondii vaccine in reducing $T$. gondii exposure for swine. Fournal of Parasitology 85, 855-860.

Mayrink, W., Mendonca-Mendes, A., de Paula, J. C., Siqueira, L. M. Marrocos Sde, R., Dias, E.S., de Andrade, H. M. and MachadoCoelho, G. L. (2013). Cluster randomised trial to evaluate the effectiveness of a vaccine against cutaneous leishmaniasis in the Caratinga microregion, south-east Brazil. Transactions of the Royal Society of Tropical Medicine and Hygiene 107, 212-219. doi: 10.1093/trstmh/trt006.

McDonald, V. and Shirley, M.W. (2009). Past and future: vaccination against Eimeria. Parasitology 136, 1477-1489. doi: 10.1017/ S0031182009006349.
McDougald, L. R. (1998). Intestinal protozoa important to poultry. Poultry Science 77, 1156-1158.

McDougald, L. R. and Jeffers, T. K. (1976). Eimeria tenella (Sporozoa, Coccidia): gametogony following a single asexual generation. Science 192, 258-259.

Miller, L. H., Good, M. F. and Milon, G. (1994). Malaria pathogenesis. Science 264, 1878-1883.

Nadim, A., Javadian, E., Tahvildar-Bidruni, G. and Ghorbani, M. (1983). Effectiveness of leishmanization in the control of cutaneous leishmaniasis. Bulletin de la Societe de pathologie exotique et de ses filiales 76, 377-383

Nadim, A., Javadian, E. and Mohebali, M. (1997). The experience of leishmanization in the Islamic Republic of Iran. La Revue de Santé de la Méditerranée Orientale 3, 284-289.

NIFA (2009). Animal systems portfolio annual report, CSREES (now the National Institute of Food and Agriculture). United States Department of Agriculture. http://www.nifa.usda.gov/about/pdfs/par_as.pdf.

NIH (2012). Appropriations of the National Institutes of Health (United States). In The NIH Almanac. http://www.nih.gov/about/ almanac/appropriations/index.htm.

Nogueira, F. S., Moreira, M. A., Borja-Cabrera, G. P., Santos, F. N., Menz, I., Parra, L. E., Xu, Z., Chu, H. J., Palatnik-de-Sousa, C. B. and Luvizotto, M. C. (2005). Leishmune vaccine blocks the transmission of canine visceral leishmaniasis: absence of Leishmania parasites in blood, skin and lymph nodes of vaccinated exposed dogs. Vaccine $\mathbf{2 3}, 4805-4810$. doi: S0264-410X(05)00530-X [pii] 10.1016/j.vaccine.2005.05.011.

Ogutu, B. R., Apollo, O. J., McKinney, D., Okoth, W., Siangla, J., Dubovsky, F., Tucker, K., Waitumbi, J. N., Diggs, C., Wittes, J., Malkin, E., Leach, A., Soisson, L. A., Milman, J. B., Otieno, L., Holland, C. A., Polhemus, M., Remich, S. A., Ockenhouse, C. F., Cohen, J., Ballou, W. R., Martin, S. K., Angov, E., Stewart, V.A., Lyon, J.A., Heppner, D. G., Withers, M.R. and Group, M.S.P.M.V.W. (2009). Blood stage malaria vaccine eliciting high antigen-specific antibody concentrations confers no protection to young children in Western Kenya. PLoS ONE 4, e4708. doi: 10.1371/ journal.pone. 0004708 .

Olotu, A., Fegan, G., Wambua, J., Nyangweso, G., Awuondo, K. O., Leach, A., Lievens, M., Leboulleux, D., Njuguna, P., Peshu, N., Marsh, K. and Bejon, P. (2013). Four-year efficacy of RTS,S/AS01E and its interaction with malaria exposure. New England Fournal of Medicine 368, 1111-1120. doi: 10.1056/NEJMoa1207564.

Olson, M. E., Morck, D. W. and Ceri, H. (1997). Preliminary data on the efficacy of a Giardia vaccine in puppies. Canadian Veterinary Fournal 38, 777-779.

Pakandl, M. (2005). Selection of a precocious line of the rabbit coccidium Eimeria flavescens Marotel and Guilhon (1941) and characterisation of its endogenous cycle. Parasitology Research 97, 150-155. doi: 10.1007/s00436005-1411-x.

Palatnik-de-Sousa, C. B., Silva-Antunes, I., Morgado Ade, A., Menz, I., Palatnik, M. and Lavor, C. (2009). Decrease of the incidence of human and canine visceral leishmaniasis after dog vaccination with Leishmune in Brazilian endemic areas. Vaccine 27, 3505-3512. doi: S0264-410X(09)00467-8 [pii] 10.1016/j.vaccine.2009.03.045.

Patel, E. H., Lubembe, D. M., Gachanja, J., Mwaura, S., Spooner, P. and Toye, P. (2011). Molecular characterization of live Theileria parva sporozoite vaccine stabilates reveals extensive genotypic diversity. Veterinary Parasitology 179, 62-68. doi: 10.1016/j.vetpar.2011.01.057.

Perlaza, B. L., Valencia, A.Z., Zapata, C., Castellanos, A., Sauzet, J.P., Blanc, C., Cohen, J., Arevalo-Herrera, M., Corradin, G., Herrera, S. and Druilhe, P. (2008). Protection against Plasmodium falciparum challenge induced in Aotus monkeys by liver-stage antigen-3-derived long synthetic peptides. European Fournal of Immunology 38, 2610-2615. doi: 10.1002/eji.200738055.

Pipano, E. (1997). Vaccines against hemoparasitic diseases in Israel with special reference to quality assurance. Tropical Animal Health and Production 29 (4 Suppl.), 86S-90S.

Radley, D. E., Brown, C. G. D., Cunningham, M.P., Kimber, C. D., Musisi, F. L., Payne, P. A., Purnell, R. E., Stagg, S. M. and Young, A. S. (1975). East coast fever: 3. Chemoprophylactic immunization of cattle using oxytetracycline and a combination of theilerial strains. Veterinary Parasitology 1, 51-60.

Reed, R. C., Louis-Wileman, V., Wells, R. L., Verheul, A. F., Hunter, R. L. and Lal, A. A. (1996). Re-investigation of the circumsporozoite protein-based induction of sterile immunity against Plasmodium berghei infection. Vaccine 14, 828-836.

Richards, W. H. G. (1966). Active immunization of chicks against Plasmodium gallinaceum by inactivated homologous sporozoites and erythrocytic parasites. Nature 212, 1492-1494. 
Roestenberg, M., McCall, M., Hopman, J., Wiersma, J., Luty, A. J., van Gemert, G. J., van de Vegte-Bolmer, M., van Schaijk, B., Teelen, K., Arens, T., Spaarman, L., de Mast, Q., Roeffen, W., Snounou, G., Renia, L., van der Ven, A., Hermsen, C. C. and Sauerwein, R. (2009). Protection against a malaria challenge by sporozoite inoculation. New England Fournal of Medicine 361, 468-477. doi: 10.1056/ NEJMoa0805832.

Rogers, W. O., Weiss, W. R., Kumar, A., Aguiar, J. C., Tine, J. A., Gwadz, R., Harre, J. G., Gowda, K., Rathore, D., Kumar, S. and Hoffman, S. L. (2002). Protection of rhesus macaques against lethal Plasmodium knowlesi malaria by a heterologous DNA priming and poxvirus boosting immunization regimen. Infection and Immunity 70, 4329-4335.

Rutgers, T., Gordon, D., Gathoye, A.M., Hollingdale, M. R., Hockmeyer, W., Rosenberg, M. and De Wilde, M. (1988). Hepatitis B surface antigen as carrier matrix for the repetitive epitope of the circumsporozoite protein of Plasmodium falciparum. Bio/Technology $\mathbf{6}$ 1065-1070.

Sadun, E. H., Wellde, B. T. and Hickman, R. L. (1969). Resistance produced in owl monkeys (Aotus trivirgatus) by inoculation with irradiated Plasmodium falciparum. Military Medicine 134, 1165-1175.

Saraiva, E. M., de Figueiredo Barbosa, A., Santos, F. N., BorjaCabrera, G.P., Nico, D., Souza, L.O., de Oliveira MendesAguiar, C., de Souza, E.P., Fampa, P., Parra, L. E., Menz, I., Dias, J. G., Jr., de Oliveira, S. M. and Palatnik-de-Sousa, C. B. (2006). The FML-vaccine (Leishmune) against canine visceral leishmaniasis: a transmission blocking vaccine. Vaccine 24, 2423-2431. doi: S0264410X(05)01217-X [pii] 10.1016/j.vaccine.2005.11.061.

Schetters, T. P. and Gravendyck, M. (2006). Regulations and procedures in parasite vaccine development. Parasitology 133 (Suppl.), S189-S195. doi: 10.1017/S0031182006001879.

Schetters, T. P., Kleuskens, J.A., Scholtes, N. C., Gorenflot, A., Moubri, K. and Vermeulen, A. N. (2001). Vaccination of dogs against heterologous Babesia canis infection using antigens from culture supernatants. Veterinary Parasitology 100, 75-86.

Schetters, T.P., Kleuskens, J.A., Scholtes, N.C., van de Crommert, J., Krijnen, E., Moubri, K., Gorenflot, A. and Vermeulen, A. N. (2006). Onset and duration of immunity against Babesia canis infection in dogs vaccinated with antigens from culture supernatants. Veterinary Parasitology 138, 140-146. doi: 10.1016/j. vetpar.2006.01.049.

Seder, R. A., Chang, L. J., Enama, M. E., Zephir, K. L., Sarwar, U. N., Gordon, I. J., Holman, L.A., James, E. R., Billingsley, P. F., Gunasekera, A., Richman, A., Chakravarty, S., Manoj, A. Velmurugan, S., Li, M., Ruben, A. J., Li, T., Eappen, A. G. Stafford, R.E., Plummer, S.H., Hendel, C.S., Novik, L., Costner, P. J., Mendoza, F. H., Saunders, J. G., Nason, M. C., Richardson, J. H., Murphy, J., Davidson, S. A., Richie, T. L., Sedegah, M., Sutamihardja, A., Fahle, G. A., Lyke, K. E. Laurens, M. B., Roederer, M., Tewari, K., Epstein, J. E., Sim, B. K., Ledgerwood, J. E., Graham, B. S., Hoffman, S. L. and the V. R. C. S. T. (2013). Protection against malaria by intravenous immunization with a nonreplicating sporozoite vaccine. Science 341, 1359-1365. doi: 10.1126/ science. 1241800
Sergent, É. and Sergent, E. (1910). Sur l' immunité dans le paludisme des oiseaux. Conservation in vitro des sporozoites de Plasmodium relictum. Immunité relative obtenue par inoculation de ces sporozoites. Comptes Rendus de l'Académie des Sciences 151 (Séance Du August 1, 1910), 407-409.

Sharman, P. A., Smith, N. C., Wallach, M. G. and Katrib, M. (2010) Chasing the golden egg: vaccination against poultry coccidiosis. Parasite Immunology 32, 590-598. doi: 10.1111/j.1365-3024.2010.01209.x.

Shkap, V. and Pipano, E. (2000). Culture-derived parasites in vaccination of cattle against tick-borne diseases. Annals of the New York Academy of Sciences 916, 154-171.

Uilenberg, G. (1999). Immunization against diseases caused by Theileria parva: a review. Tropical Medicine and International Health 4 , A12-A20.

USDA (2012). FY 2012 budget summary and annual performance plan of the United States Department of Agriculture. http://www.obpa.usda.gov/ budsum/FY12budsum.pdf.

Vincke, I. H. and Lips, M. (1948). Un nouveau plasmodium d'un rongeur sauvage du Congo, Plasmodium berghei $\mathrm{n}$. sp. [A new plasmodium of a wild rodent of Congo, Plasmodium berghei n. sp.]. Annales de la Société Belge de Médecine Tropicale 28, 97-104.

Wallach, M. G., Ashash, U., Michael, A. and Smith, N. C. (2008). Field application of a subunit vaccine against an enteric protozoan disease. PLoS ONE 3, e3948. doi: 10.1371/journal.pone.0003948.

Weston, J. F., Heuer, C. and Williamson, N. B. (2012). Efficacy of Neospora caninum killed tachyzoite vaccine in preventing abortion and vertical transmission in dairy cattle. Preventive Veterinary Medicine 103, 136-144. doi: S0167-5877(11)00266-2 [pii] 10.1016/j. prevetmed.2011.08.010

Wilkins, M. F., O'Connell, E. and Te Punga, W. A. (1988) Toxoplasmosis in sheep III. Further evaluation of the ability of a live Toxoplasma gondii vaccine to prevent lamb losses and reduce congenital infection following experimental oral challenge. New Zealand Veterinary Fournal 36, 86-89.

Williams, R. B. (2002). Fifty years of anticoccidial vaccines for poultry (1952-2002). Avian Diseases 46, 775-802.

Williams, R. B., Johnson, J. D. and Andrews, S. J. (2000). Anticoccidial vaccination of broiler chickens in various management programmes: relationship between oocyst accumulation in litter and the development of protective immunity. Veterinary Research Communications 24, 309-325.

Witonsky, S., Morrow, J. K., Leger, C., Dascanio, J., BuechnerMaxwell, V., Palmer, W., Kline, K. and Cook, A. (2004). Sarcocystis neurona-specific immunoglobulin $\mathrm{G}$ in the serum and cerebrospinal fluid of horses administered $S$. neurona vaccine. Fournal of Veterinary Internal Medicine 18, 98-103.

Yin, H., Luo, J. and Lu, W. (2008). Control of tropical theileriosis with attenuated schizont vaccine in China. Vaccine 26 (Suppl. 6), G11-G13. doi: $10.1016 /$ j.vaccine. 2008.09 .069

Zhang, Z. H. (1997). A general review on the prevention and treatment of Theileria annulata in China. Veterinary Parasitology 70, 77-81.

Zintl, A., Mulcahy, G., Skerrett, H. E., Taylor, S. M. and Gray, J. S. (2003). Babesia divergens, a bovine blood parasite of veterinary and zoonotic importance. Clinical Microbiology Reviews 16, 622-636. 